\title{
Teachers' Effectiveness and Students' Academic Achievement in Senior Secondary School Civic, Osun State Nigeria
}

\author{
Babatunde Adeniyi ADEYEMI \\ Institute of Education, Obafemi Awolowo University, Ile-Ife, Nigeria. \\ Email:adeyemibabs2003@yahoo.com
}

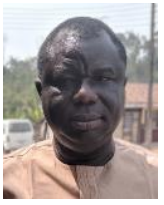

\begin{abstract}
The study assessed the level of teaching effectiveness of Civic teachers in Osun State. It also determined the relationship between teachers' effectiveness and senior secondary school students' academic achievement and examined the difference between the academic achievement of the students taught by male Civic teachers and those taught by female Civic teachers in the study area. The study employed Correlational research design and the population for the study comprised of Civic teachers and the senior secondary school students in Osun State. The sample size for the study consisted of forty (40) Civic teachers and two hundred (200) students selected using multistage sampling procedure. A research question and two hypotheses were raised to guide the study. Two instruments: Teachers' Effectiveness Rating Scale (TERS) and Civic Achievement Test (CAT) were developed and used for data collection. The two instruments were given to experts in Civic Education and Test and Measurement for face and content validity and were later subjected to a reliability test using Pearson moment product correlation which yielded values of 0.65 and 0.72 respectively. Data collected were analysed using frequency counts, simple percentages, mean, standard deviation, linear regression and t-test statistics. Findings of the study showed that the level of teaching effectiveness of Civic teachers in the study area is moderate. The study concluded that teachers' effectiveness is a correlate of senior secondary school students' academic achievement in Civic in Ife Central Local Government Area of Osun State.
\end{abstract}

Keywords: Teachers, Effectiveness, Students, Academic, Achievement, Civic.

Citation | Babatunde Adeniyi ADEYEMI (2020). Teachers Effectiveness and Students' Academic Achievement in Senior Secondary School Civic, Osun State Nigeria. Asian Journal of Social Sciences and Management Studies, 7(2): 99-103. History:

Received: 5 February 2020

Revised: 13 March 2020

Accepted: 17 April 2020

Published: 11 May 2020

Licensed: This work is licensed under a Creative Commons

Attribution 3.0 License (cc) E E

Publisher: Asian Online Journal Publishing Group

\section{Contents}

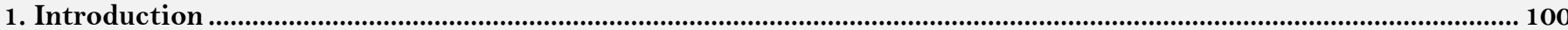

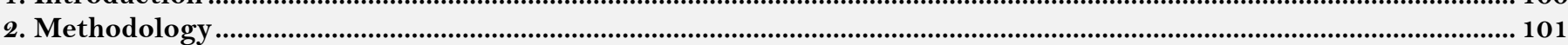

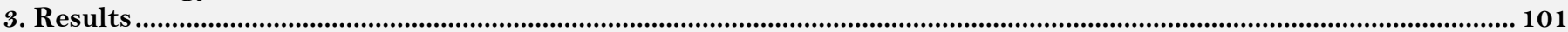

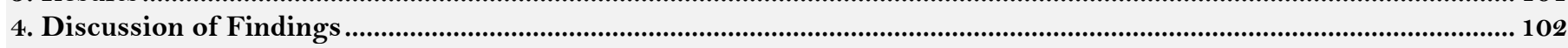

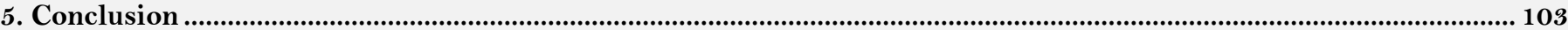

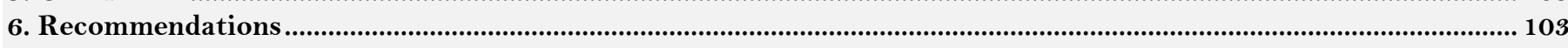

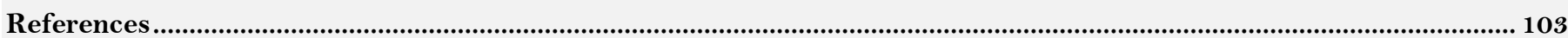

Funding: This study received no specific financial support.

interests Interests: The author declares that there are no conflicts of Transparency: The author confirms that the manuscript is an honest, ccurate, and transparent account of the study was reported; that no vital study as planned have been explained.

Ethical: This study follows all ethical practices during writing. 


\section{Contribution of this paper to the literature}

This study has provided empirical evidences that showed the level of teaching effectiveness of Civics teachers in the study area. Not only that, the study revealed that there was a significant relationship between teachers' effectiveness and senior secondary school students' academic achievement in Civic in the study area. In addition, the study showed that there was no significant difference between the academic achievement of students taught by male Civic teachers and those taught by female Civic teachers in the study area.

\section{Introduction}

Education is key for human development. Education is a tool that brings about upliftment and growths for people. Alade (2004) asserted that education is an instrument for children in the nursery school to be well developed and grow in their skills and potentials. Education allows for survival among pupils in the school. It is the foundation to which skills are developed among the learners and the society at large.

Teaching is such a profession that is practiced among people who are passionate and have the skill of developing people and wanting them to grow. A teacher must be ready to motivate, encourage, counsel, educate and develop others for the sake of development. Teachers must not see teaching job as a stepping stone to other professions, they must it as an opportunity to build the lives of others via contents and practice (Okolocha \& Onyeneke, 2013). Teaching is geared and should be focused on human sustainable development and effective growth (Oyekan, 2000).If the educational tanning of teachers is well built, there would be room for effective teaching among the learners as well as educators. For effective teaching to be brought to limelight, teachers must be able to give room for creativity, intellectualism, love, hospitality, love for wisdom and the ability to understand the theme of individual differences. The extent of the competence of teachers, the level of adaptation, the strength of understanding of the teachers and many more have to be well understood. If teaching would be meaningful and effective, the teacher must demonstrate high level of intelligence, skills and knowledge in line with pedagogical delivery (Adeyemi, 2016). One of the main differences in the junior Secondary School (JSS) and Senior Secondary School (SSS) curricula is the fact that teachers must be able and ready to demonstrate high level of mastery of the subject to be taught. Teachers must be well grounded in the subjects that have been trained to teach the learners. Such virtues as classroom evaluation, assessment of content learnt and many more should not be put aside in the teaching profession. Teachers should allow for effective classroom interaction as a way of build and evaluating the extent to which learners have learnt (Adeyemi, 2019).

Academic competencies can be seen as skills that have been developed by the teachers to make sure that the students are academically achieved and competent. The principal attributes of teaching should be well understood by teachers to give room for effective teaching deliveries among teachers (Akpan, 2002). An effective teacher is such that does not keep stop learning and understanding the trends in teaching profession. The teaching styles and skills of the teachers are scored by the level and extend of performance of learners academically. Most research had revealed that the best place to locate the answer to those questions is to ask the students who are being taught (Daniel \& James, 2007).In the word of Akomolafe (2010) attention on students' achievement, quality teaching responsive to students learning opportunities, pedagogical practices play prominent roles in effective teaching deliveries of teachers. The school, teachers and the society at large should be ready to assist learners to perform well and effectively in the roles as professional teachers. The school curriculum should be focused on developing the holistic child such as developing the intellectual, physical and social skills.

Academic performance can be seen as the level or extend to which the goals of education or a particular curriculum has been achieved among learners. The academic performance of the learners is dependent on the ability of the teachers to teach effectively and educate learners from their reservoir of knowledge. The level of academic achievement of learners is achieved via the ability of learners to demonstrate their competence via writing of examination of test after been exposed to content under the tutelage of teachers. When a test or examination is to be written, learners have anxiety, fear and discouragement. This does not stop learners from showing their level of academic competence and academic achievement. A school is then seen as an institution where learners are exposed to content to test their level of intelligence and academic performance from one stage of education to the other. Ademola (2007) in his findings found that though there are more female teachers in the school than make teachers, female teachers are still more absent in the school that the male teachers. This might be due to the fact that some of them are children that they attend to on the daily bases before finding their way to the school. However, Akinmusire (2012) revealed that more learners taught by female teachers perform more than learners that are taught by the male teachers. The core of this study is therefore to investigate teachers' effectiveness and students' academic performance in Civics in Osun State, Nigeria.

\subsection{Statement of the Problem}

Teachers' primary role of transmission of knowledge and skills is never in dispute hence the adequacy and quality for better service delivery of teachers need to be assessed on a regular basis. Therefore, the performance of teachers should be glaring and persistent for their learners to perform well academically and social in and out of the school. It is however sad to note that most learners have been faced with low academic performance being the fact that the teachers are not well skilled and passionate among the learners. This extent and level of academic performance therefore borders on the quality of human and material resources which are available during their schooling. This study therefore aims at investigating the influence of teacher's effectiveness on students' academic achievement on Civic.

\subsection{Purpose of the Study}

The purpose of the study is to find out the relationship between teacher effectiveness and students' academic achievement in civics. Specifically, this study sought to;

(i) Assess the level of teaching effectiveness of Civic teachers in Ife Central Local Government Area of Osun State. 
(ii) Determine the relationship between teachers' effectiveness and senior secondary school students' academic achievement in Civic in the study area.

(iii) examine the difference between the academic achievement of the students taught by male Civic teachers and those taught by female Civic teachers in the study area.

\subsection{Research Question}

What is the level of teaching effectiveness of Civic teachers in Osun State?

\subsection{Hypotheses}

(i) There is no significant relationship between teachers' effectiveness and senior secondary school students' academic achievement in Civic in the study area.

(ii) There is no significant difference between the academic achievement of students taught by male Civics teachers and those taught by female Civic teachers in the study area.

\section{Methodology}

This study adopted a correlational research design. The population for the study consisted of all secondary school Civic teachers and students in Osun State. The sample size for the study comprised forty (40) Civic teachers and two hundred (200) senior secondary school students selected using multistage sampling procedure. Two senatorial districts were selected from the three in the region using simple random sampling technique. Ten Local Government Areas (LGAs) were selected from each of the selected senatorial districts. From each LGA, two senior secondary schools were then selected using simple random sampling technique. One Civic teacher and five students were then selected from each school using simple random sampling technique. Two instruments were designed and administered for data collection with the help of trained research assistance. These instruments were: Teachers Effectiveness Rating Scale (TERS) and Civic Achievement Test (CAT). The TERS was designed in two major sections. Section A deals with personal information of the respondents while Section B contains four major items with five sub-items under each. The second instrument tagged CAT was also designed in two major sections. Section A deals with personal information of the respondents while Section B consisted of objective questions with options A - D. The two instruments were given to the experts in Civic Education and Test and Measurement for face and content validity. The instruments were trial tested in a pilot study outside the scope of the study using a sample of ten (10) for the Teachers Effectiveness Rating Scale (TERS) and fifty (50) Civic Achievement Test (CAT) through Pearson moment product correlation and the results yielded values of 0.65 and 0.72 respectively. The values obtained indicated that the instruments are good enough and reliable for the study. Data collected were analysed using frequency counts, simple percentage, mean, standard deviation, linear regression and t-test statistical tools.

\section{Results}

Table-1. Correlational statistics of socio-demographic information of secondary school Civic teachers in the study area.

\begin{tabular}{c|c|c|c}
$\mathbf{N}=\mathbf{4 0}$ & \multicolumn{3}{|c}{} \\
\hline $\mathbf{S} / \mathbf{N}$ & Variables & Frequency (f) & Percentage (\%) \\
\hline 1. & Gender & & 45.0 \\
\hline & Male & 18 & 55.0 \\
\hline & Female & 22 & 15.0 \\
\hline 2. & Age & & 50.0 \\
\hline & Below 30 & 6 & 35.0 \\
\hline & $30-40$ & 20 & 20.0 \\
\hline & 41 and above & 14 & 72.5 \\
\hline 3. & Marital Status & & 7.3
\end{tabular}

Table-2. Correlational statistics of socio-demographic information of senior secondary school students of civic in the study area.

\begin{tabular}{c|c|c|c}
$\mathbf{N}=\mathbf{2 0 0}$ & \multicolumn{3}{l}{} \\
\hline $\mathbf{S} / \mathbf{N}$ & Variables & Frequency (f) & Percentage (\%) \\
\hline 1. & Sex & & \\
\hline & Male & 92 & 46.0 \\
\hline & Female & 108 & 54.0 \\
\hline 2. & Age & & 45.0 \\
\hline & Below 15 & 90 & 55.0 \\
\hline & Above 16 & 110 & 37.5 \\
\hline & Class & & 35.0 \\
\hline 3. & SSS 1 & 75 & 27.5
\end{tabular}

Results in Table 1 showed the descriptive statistics of socio-demographic information of Civic teachers in senior secondary schools in the study area. From the table, it can be deduced that $18(45.0 \%)$ are males while 
$22(55.0 \%)$ are females even as $6(15.0 \%), 20(50.0 \%)$ and $14(35.0 \%)$ are in the age range of below $30,30-40$ and 41 and above respectively. Considering marital status, 8(20.0\%), 29(72.5\%) and 3(7.3\%) are single, married and divorced respectively in the study area. Results in Table 2 showed the descriptive statistics of socio-demographic information of the respondents in the study area. It can be observed from the table that 92(46.0\%) are males while $108(54.0 \%)$ are females. On age range, $90(45.0 \%)$ are below 15 while $110(55.0 \%)$ are above 16 years of age even as $75(37.5 \%), 70(35.0 \%)$ and $55(27.5 \%)$ are in SSS 1, SSS 2 and SSS 3 respectively in the study area.

Research Question: What is the level of teaching effectiveness of Civic teachers in Ife Central Local Government Area of Osun State?

In order to answer this research question, data collected on the Civic teachers' effectiveness were subjected to correlational statistics to determine the level using the average result of standard deviation and the results are presented in Table 3 .

Low $=1.00-1.39$, Moderate $=1.40-1.59$, High $=1.60-2.00$

Table-3. Correlational statistics of the level of teaching effectiveness of civic teachers in the study area.

\begin{tabular}{c|l|c|c}
\hline S/N & General Effectiveness & Mean & Standard Deviation \\
\hline 1. & Classroom managemen & 2.20 & 1.50 \\
\hline 2. & Personality & 2.00 & 1.58 \\
\hline 3. & Teaching techniques and methods & 1.95 & 1.77 \\
\hline 4. & Appearance & 2.22 & 1.44 \\
\hline Average results & & 2.09 & 1.57 \\
\hline
\end{tabular}

Results in Table 3 showed correlational statistics of the level of teaching effectiveness of Civic teachers in Ife Central Local Government Area of Osun State. Considering the average result of the standard deviation, it can be drawn out from the table that the level of teaching effectiveness of Civics teachers in the study area is moderate at $(\mathrm{SD}=1.57)$.

\subsection{Hypotheses}

$H_{o l}$ : There is no significant relationship between teachers' effectiveness and senior secondary school students' academic achievement in Civic in the study area.

In order to test this hypothesis, data collected on teachers' effectiveness and students" academic achievement in Civic were subjected to linear regression analysis and the results are presented in Table 4.

Table-4. Regression analysis of the relationship between teachers' effectiveness and senior secondary school students' academic achievement in Civic in the study area.

\begin{tabular}{c|c|c|c|c|c}
\hline Model & Sum of Squares & df & Mean Square & F & Sig. \\
\hline Regression & 103.068 & 1 & 34.356 & 4.096 & .007 \\
\hline Residual & 2902.087 & 198 & 8.388 & & \\
\hline Total & 3005.154 & 199 & & & \\
\hline $\mathrm{R}=0.185 \mathrm{a}, \quad \mathrm{R}$ Square $=0.034, \quad$ Adjusted R Square $=0.026$ \\
Note: F = 4.096, p $<0.05$.
\end{tabular}

Note: $\mathrm{F}=4.096, \mathrm{p}<0.05$

Results in Table 4 showed that there is significant relationship between teachers' effectiveness and senior secondary school students' academic achievement in Civic in the study area $(F=4.096, p<0.05)$. Therefore, the null hypothesis that states that there is no significant relationship between teachers' effectiveness and senior secondary school students' academic achievement in Civic in the study area is hereby rejected. The R Square value of $0.185^{\mathrm{a}}$ indicated a high degree of correlation between teachers' effectiveness and senior secondary school students' academic achievement in Civic in the study area. Also, the R Square value of 0.034 accounted for a low variation of $3.4 \%$ in teachers' effectiveness and senior secondary school students' academic achievement in Civic in the study area.

$H_{o s:}$ There is no significant difference between the academic achievement of students taught by male Civics teachers and those taught by female Civic teachers in the study area.

In order to test this hypothesis, data collected on students' academic achievement considering the numbers of those taught by male Civic teachers and those taught by female Civic teachers were subjected to t-test analysis and the results are presented in Table 5.

Table-5. t-test analysis of the difference between the academic achievement of students taught by male Civic teachers and those taught by female Civic teachers in the study area.

\begin{tabular}{l|c|c|c|c|c|c}
\hline Groups & N & Mean & S.D & df & t & Sig.(2-tailed) \\
\hline Students taught by male teachers & 89 & 32.44 & 12.22 & 198 & 3.235 & .215 \\
\hline Students taught by female teachers & 111 & 34.18 & 13.46 & & & \\
\hline
\end{tabular}

Note: $\mathrm{t}=3.235, \mathrm{p}>0.05$.

Results in Table 5 showed that there is no significant difference between the academic achievement of students taught by male Civic teachers and those taught by female Civic teachers in the study area $(\mathrm{t}=3.235, \mathrm{p}>0.05)$. Hence, the null hypothesis that states that there is no significant difference between the academic achievement of students taught by male Civic teachers and those taught by female Civic teachers in the study area is hereby not rejected.

\section{Discussion of Findings}

Findings of the study showed that the level of teaching effectiveness of Civic teachers in the study area is moderate. The result is in line with the findings of Stronge, Ward, and Grant (2011); Aina (2013) they 
acknowledged that teaching effectiveness among teachers can be traced to their ability to utilize both human and non-human resources to bring about effective teaching-learning process and that the level of teaching effectiveness is relatively moderate in some society and high in others but low ow in underdeveloped areas.

Results of the study further revealed that there is significant relationship between teachers' effectiveness and senior secondary school students' academic achievement in Civic in the study area. The result supports the findings of Oliver and Reschly (2007) they submitted that effectiveness of teachers determines academic performance of students since effective teaching-learning process will be well actualized. In the same vein, Orji (2014) pointed out that when teachers discharge their responsibilities meaningfully, it will prompt and boast the performance of learners. Finally, results of the study indicated that there is no significant difference between the academic achievement of students taught by male Civic teachers and those taught by female Civic teachers in the study area according to the researcher.

\section{Conclusion}

Based on the findings of this study, it can therefore be concluded that teachers' effectiveness is a correlate of senior secondary school students' academic achievement in Civic in Ife Central Local Government Area of Osun State.

\section{Recommendations}

The following recommendations are put forward based on the findings of this study:

1. There should be opportunity by the government for the purpose of learning via seminars, conferences and training.

2. There should be room for motivation and reinforcement for teachers as a way of making sure that they are motivated for effective teaching and educational practices.

3. Teachers should always emphasize and encourage all eligible students to actively participate in civic activities. Classroom teaching/learning should not be limited to learning to pass alone but to inculcate positive habits and character expected of a good citizen.

4. Teachers should equip their students with adequate civic knowledge as well emphasize the essence of knowledge to their practical lives as responsible individuals.

5. In addition to fostering adequate civic knowledge of their students, teachers should also model a positive attitude towards civic obligations as this can encourage students to emulate good character and behaviour. This can be achieved by appropriately relating acquired knowledge to practical principles of life.

\section{References}

Ademola, B. (2007). Teachers' effectiveness and gender as correlates of students' academic achievement in English Language in Ondo State. African Journal of Education Research, 2(182), 12-20.

Adeyemi, B. (2016). The efficacy of social studies teachers' competence in the use of playway method in lower primary schools in Osun State, Nigeria. Journal of Education and Human Development, 5(1), 249-255.Available at: https://doi.org/10.15640/jehd.v5n 1a25.

Adeyemi, B. A. (2019). A study of relationship between pedagogical knowledge and practice among senior secondary school civic teachers in Osun State Nigeria. International Journal of Research and Innovation in Social Science, 3(4), 90-95.

Aina, J. K. (2013). Effective teaching and learning in science education through information and communication technology [ICT]. IOSR Journal of Research and Method in Education, 2(5), 43-47.Available at: https://doi.org/10.9790/7388-0254347.

Akinmusire, P. A. (2012). Critical reading and story-mapping instructional strategies as determinants of Nigeria certificate in Education teachers classroom practices and achievement in English reading comprehension. Unpublished Ph.D Thesis, University of Ibadan.

Akomolafe, C. O. (2010). Strategies and challenges of ICT: An infrastructural development for university education in Nigeria. Retrieved from www.herpnet.org/revitalizationofhigher/chapter/pdf.

Akpan, B. B. (2002). Basic concepts in educational psychology. Uyo: Academic Publishers Ltd.

Alade, I. A. (2004). Improving the status of vocational technical education: A route to National development. Teachers' Mandate on Education and Social Development in Nigeria. In D. F. Elaturoti and K. Babarinde (Eds) (pp. 95-105). Ibadan: Sterling-Horden Publishers.

Daniel, S. N., \& James, K. G. (2007). The effect of in-service education and training (INSET) programmes in mathematics and science on classroom interaction: A case study of primary and secondary schools in Kenya. Africa Education Review, 4(1), 104-126.Available at: https://doi.org/10.1080/18146620701412191.

Okolocha, C. C., \& Onyeneke, E. N. (2013). Secondary school principals' perception of business studies teachers' teaching effectiveness in Anambra State, Nigeria. Journal of Education and Practice, 4(2), 171-179.

Oliver, R. M., \& Reschly, D. J. (2007). Effective classroom management: Teacher preparation and professional development. Washington. DC: National Comprehensive Centre for Teachers Quality.

Orji, N. (2014). Relationship between science teachers' classroom management effectiveness and students' outcome in Chemistry. International Journal of Modern Education Research, 1(1), 11-14.

Oyekan, S. O. (2000). Foundations of teacher education. Okitipupa: Ebun-Oluwa Press.

Stronge, J. H., Ward, T. J., \& Grant, L. W. (2011). What makes good teachers good? A cross-case analysis of the connection between teacher effectiveness and student achievement. Journal of Teacher Education, 62(4), 339-355.Available at: https://doi.org/10.1177/0022487111404241. 